Avoimesti luettavissa osoitteessa http://journal.fi/ainedidaktiikka

ainedidaktiikka

\title{
Kirja-arvostelu
}

Allender, T., Clark, A., \& Parkes, R. (toim.) (2019). Historical thinking for history teachers. A new approach to engaging students and developing historical consciousness. Lontoo: Routledge. $352 \mathrm{~s}$.

Lévesque, S., \& Croteau, J-P. (2020). Beyond history for historical consciousness. Students, narrative, and memory. Toronto: University of Toronto Press. $197 \mathrm{~s}$.

\section{Historianopetuksen peruskäsitteiden äärellä}

Historiallisen ajattelun ja historiatietoisuuden käsitteet hallitsevat historianopetuksen tutkimusta. Ensin mainittu käsite on ollut vilkkaan tutkimuksen kohteena etenkin angloamerikkalaisissa maissa. Historiatietoisuuteen kohdistunut tutkimus on puolestaan kummunnut eurooppalaisesta perinteestä. Viime vuosina historiandidaktisen tutkimuksen raja-aidat ovat madaltuneet ja mainittuihin käsitteisiin kohdistuu tutkimusta eri puolilla maailmaa. Runsaslukuisen tutkimuksen voisi kuvitella ammentaneen mainitut käsitteet tyhjiin, mutta toisin on käynyt. Historiallisen ajattelun ja historiatietoisuuden käsitteitä määritellään koko ajan uudelleen. Jatkuvasti myös kertyy uutta tutkimustietoa niiden merkityksestä historiallisen ajattelutavan omaksumiseen.

Historiandidaktiikan tutkijat ovat tiedejulkaisemisen nykytrendin myötä siirtyneet julkaisemaan tiedejournaaleissa. Heiltä ilmestyy yhä harvemmin monografioita, ja myös antologiajulkaiseminen tuntuu vähentyneen pois lukien massiiviset käsikirjat, joita on lyhyen ajan sisällä tullut puolenkymmentä. Kun hiljattain australialaisilta tutkijoilta julkaistiin historiallisen ajattelun opettamista käsittelevä kirjoituskokoelma ja kanadalaisilta tutkijoilta monografia nuorten historiatietoisuudesta, niihin oli syytä tutustua, sillä kirjojen otsikoissa esiintyvät käsitteet ovat avainkäsitteinä myös suomalaisissa opetussuunnitelmissa.

Historiallista ajattelua ja historiatietoisuutta käsitteleviä tutkimuksia lukiessa voi saada vaikutelman, että pyörää keksitään koko ajan uudestaan. Eri puolilla maailmaa tutkijat käyttävät kuitenkin käsitteitä eri lailla. 


\section{Ainedidaktiikka 5(1) (2021)}

Käsitteiden sisältö on myös muuttunut aikojen saatossa. Esimerkiksi eettisen näkökulman korostaminen on varsin tuore ja leimallisesti kanadalaislähtöinen osa historiallisen ajattelun määritelmää. Historiallisen ajattelun ja historiatietoisuuden käsitteistä kirjoittavien olisi hyvä tuntea käyttämiensä käsitteiden kehitys. Monet australialaisantologian kirjoittajista johtavat opetusfilosofiansa englantilaisen Schools Council History -hankkeen perinnöstä, jolle on paljolti velkaa myös viime vuosikymmenten historiandidaktinen tutkimus Yhdysvalloissa ja Kanadassa. Osa kirjoittajista tunnistaakin käyttämiensä käsitteiden juuret.

Historical thinking for history teachers - A new approach to engaging students and developing historical consciousness perehdyttää nimensä mukaisesti historianopettajat uudenlaiseen lähestymistapaan. Otsikon muotoilu kertoo siitä, ettei kaikkialla Australiassa historiallisen ajattelun opettaminen ole tähän mennessä ollut opetuksen keskiössä. Tältä osin yhtymäkohdat Suomen tilanteeseen ovat ilmeiset (ks. Rantala ym., 2020). Teos avaa historiallista ajattelua painottavan opetussuunnitelman taustoja sekä opastaa historian taitojen opettamiseen ja arviointiin. Kirjassa käsitellään myös historianopetusten erilaisia lähestymistapoja sekä Australian alkuperäisväestön historian opettamista. Käydyt kamppailut historianopetuksen sisällöstä eli niin sanotut historiasodat ovat näkyvästi esillä, samoin aiemman eheytetyn opetussuunnitelman haitalliset vaikutukset historian oppiaineelle.

Yhtenäistä kansallista kertomusta havittelevat konservatiivipoliitikot näyttäytyvät teoksessa muutoksen jarruna. Heidän mukaansa historianopetuksesta on häivytetty kansallisen ylpeyden aiheet ja tilalle otettu vähemmistöjen kaltoinkohtelun käsittely. Lisäksi yhtenäisestä tarinasta on siirrytty yksittäisten saarekkeiden syvällisempään opiskeluun. Konservatiivipoliitikot valittavat nuorten heikosta historiatietämyksestä; edes maan ensimmäisen pääministerin nimi ei ole nuorille tuttu. Artikkelien kirjoittajat vastaavat kritiikkiin perustelemalla historianopetuksen muutosta tiedon tuottamisen ja käyttämisen tapojen muuttumisella. Muistihistoriaa tärkeämpää on kirjoittajien mukaan kyetä toimimaan kriittisinä kansalaisina. Kirjoittajien perustelut ovat tuttuja historiandidaktikkojen vastaavista puheenvuoroista muualla.

Historical thinking for history teachers perustelee historiallisen ajattelun opetuksen ylivertaisuutta verrattuna aiempaan sisältöjä painottavaan opetukseen. Teoksessa on peräti 27 kirjoittajaa, mukana australialaisia historiandidaktiikan isoja nimiä mutta myös tutkijanuran alkuvaiheessa olevia opettajia. Vaikka kokonaisuutena kirja avaa onnistuneesti Australian historiaopetuksen kehitystä ja nykytilaa, turhan monessa kirjoituksessa tarkastellaan samoja asioita. Teoksen toimittajilta olisi odottanut toiston karsimista, mutta heidän tehtävänsä on ollut vaikea. Kun kirjoittajien joukossa on uran eri vaiheessa olevia tutkijoita, on ollut vaikea päättää, keiden olisi pitänyt luopua avainkäsitteidensä määrittelystä. Teoksen toinen ongelma liittyy antologioille tyypilliseen artikkelien epätasaisuuteen. Lisäksi tekstien sisällön rytminvaihdos kirjan puolivälissä rikkoo teoksen yhtenäisyyttä. Teoksen alkupuolen artikkelit käsittelevät isoja kysymyksiä ja jälkipuolen artikkelit kohdistetumpia kysymyksiä, kuten draaman käyttöä historianopetuksessa. Saattaa käydä niin, että 
tutkijat lukevat kirjan alkuosan ja opettajat jälkimmäisen. Teoksessa olisi ollut aineksia kahteen erilliseen kirjaan.

Australialaisen antologian alaotsikossa esiintyvä historiatietoisuus jää historiallisen ajattelun käsitteen varjoon. Historialliseen ajatteluun aiemmin keskittynyt kanadalaistutkija Stéphane Lévesque (2009) julkaisi kuitenkin viime vuonna kollegansa Jean-Philippe Croteaun kanssa tutkimuksen Beyond history for historical consciousness kanadanranskalaisten nuorten historiatietoisuudesta. Kirjaa onkin sopiva lukea australialaisantologian rinnalla.

Lévesque ja Croteau selvittivät noin 16-vuotiaiden kanadanranskalaisten narratiiveja yhteisestä menneisyydestä. Tutkimus osoittaa quebeckiläis- ja ontariolaisnuorten käsitysten poikkeavan toisistaan. Quebecin provinssissa, jossa ranskankieliset ovat enemmistönä, nuoret kiinnittyivät vahvemmin omaan provinssiinsa kuin Kanadaan, kun taas Ontariossa, jossa ranskankieliset ovat vähemmistönä, nuoret näkivät itsensä ensisijaisesti kanadalaisina. Tutkimus kohdistui kielen, sukupuolen, maantieteellisen alueen ja kollektiivisen identiteetin yhteyksiin nuorten historiatietoisuudessa.

Tutkijat keräsivät aineistonsa tehtävällä, jossa he pyysivät vastaajia kirjoittamaan, miten nämä näkevät kanadanranskalaisten historian. Saamansa kirjoitelmat he luokittelivat edustamaan neljää näkemystä kanadanranskalaisten menneisyydestä, nykyisyydestä ja tulevaisuudesta. Yhteen luokkaan he sijoittivat kirjoitelmat, jotka kuvasivat myönteisessä valossa ranskankielisten kanadalaisten kamppailua itsenäisyydestään. Toisessa luokassa olivat kirjoitelmat, jotka yhtäältä toivat esille ranskankielisten kohtaamia vastoinkäymisiä mutta toisaalta kuvasivat heidän onnistumisiaan. Ranskankielisten tappiota käsittelevien, kolmanteen luokkaan sijoitettujen kirjoitelmien pääsävy oli pessimistinen ja painotti englanninkielisten ylivaltaa. Neljättä luokkaa edustivat neutraalit kirjoitelmat. Yllättäen ranskankieliseen vähemmistöön kuuluvien Ontarion nuorten menneisyyskertomukset osoittautuivat provinssissaan enemmistöön kuuluvien quebeckiläisnuorten narratiiveja myönteisemmiksi.

Edellä kuvatun luokittelun lisäksi tutkijat tulkitsivat teksteistä, miten nuoret kuvaavat kansakunnan rakentamista, modernisaatiota, alkuperäiskansojen asemaa ja omaa henkilöhistoriaansa. Tytöt ja pojat suhtautuivat menneisyyteen eri tavoin. Pojat käsittelivät kirjoitelmissaan sotia ja konflikteja tyttöjen keskittyessä henkilö- ja sosiaalihistorian kuvaamiseen. Tytöt kirjoittivat poikia enemmän minämuodossa sijoittaen itsensä vahvemmin aktiivisiksi kertojiksi. Tytöt myös asennoituivat menneisyyteen jonkin verran poikia myönteisemmin. Lévesque ja Croteau toteavat tyttöjen ja poikien erojen olevan sosiaalisesti rakentuneita ja kontekstiriippuvaisia, joten universaaleja yleistyksiä ei niistä voi tehdä. Alkuperäiskansat eivät juuri lainkaan esiintyneet nuorten kirjoituksissa ja hävisivät kokonaan mitä lähemmäs tätä päivää tultiin.

Lévesquen ja Croteaun tulokset ovat kiinnostavia, joskin kirjoittajat olisivat voineet enemmän selittää niitä. Yksi selitys quebeckiläisnuorten narratiiveissa esiintyvään vahvaan alueelliseen kiinnittymiseen löytyy 


\section{Ainedidaktiikka 5(1) (2021)}

historiakulttuurista, joka ylläpitää Quebeckin ranskalaisen historian suurkertomusta. Sen on katsottu estävän kanadanranskalaisten ja -englantilaisten kulttuurista lähentymistä.

Narratiivinen kompetenssi, jonka kirjoittajat nostaisivat opetuksen tavoitteeksi historiallisen ajattelun rinnalle, tarkoittaa ymmärrystä menneisyyskertomusten monitahoisuudesta ja siitä, ettei ole olemassa yhtä ylivertaista menneisyyskertomusta. Koulussa ja epävirallisen historiakulttuurin tuotteissa nuoret näkevät usein valmiiksi rakentuneen menneisyyskertomuksen eli joko kansallisen (kanadalaisen) tai alueellisen (quebeckiläisen) suurkertomuksen. Lévesquen ja Croteaun mukaan nuorten pitäisi kuitenkin oppia arvioimaan menneisyyskertomusten kestävyyttä historiatieteen tarjoamilla työkaluilla. Nuorten pitäisi oppia selvittämään, miten menneisyyskertomukset ovat rakentuneet ja millaisia vaikutuksia niillä on ihmisiin. Kirjoittajien mukaan nuoret eivät koulussa riittävästi pääse työstämään menneisyyskertomuksia eikä heidän narratiivinen kompetenssinsa siten kehity. Myös nuorten reflektiivinen historiatietoisuus jää näin ollen kehittymättä.

Lévesquen ja Croteaun sanoman voi pelkistää näkemykseen, jonka mukaan pelkkä historiallisen ajattelun opettaminen ei riitä, vaan nuoret on perehdytettävä menneisyyskertomusten rakentumiseen ja narratiiviseen luonteeseen. He olisivat valmiita nostamaan narratiivin historian metakäsitteisiin - sinne historiallisen ajattelun käsitteiden rinnalle, joista australialaistutkijat kirjoittivat omassa teoksessaan.

\section{Jukka Rantala}

Kasvatustieteellinen tiedekunta, Helsingin yliopisto

\section{Lähteet}

Lévesque, S. (2009). Thinking historically. Educating students for the twenty-first century. Toronto: University of Toronto Press.

Rantala, J., Puustinen, M., Khawaja, A., van den Berg, M., \& Ouakrim-Soivio, N. (2020). Näinkö historiaa opitaan? Helsinki: Gaudeamus. 